\title{
Mount Moco: its importance to the conservation of Swierstra's Francolin Pternistis swierstrai and the Afromontane avifauna of Angola
}

\author{
MICHAEL S. L. MILLS, FABIO OLMOS, MARTIM MELO and \\ W. RICHARD J. DEAN
}

\section{Summary}

The forests of the Angolan highlands are the smallest and most isolated of the Afromontane centres of endemism. Despite their high biodiversity value and small, fragmented extent of less than 200 ha, they remain entirely unprotected. Here we draw attention to their uniqueness and the threats to their conservation. We specifically highlight the importance of Mt Moco to bird conservation and describe current forest cover and condition. Sixty-four endemic/near-endemic species/subspecies and taxa with isolated populations are associated with the highlands of western Angola. All 19 forest-dependent taxa are among the 233 species recorded at Mt Moco, which include a rich diversity of montane specialists. Swierstra's Francolin Pternistis swierstrai is the only threatened endemic. In 2009, 10 of 30 forest patches at Mt Moco larger than 0.5 ha were surveyed for this species. It occurred in seven of these surveyed patches, at a mean minimum density of 0.95 pair $\mathrm{ha}^{-1}$ in forest patches $>_{1}$ ha. Based on extrapolations of this figure, we estimate a minimum of 75 pairs of Swierstra's Francolin at Mt Moco, and 185-420 pairs worldwide. Due to both limited range and small population size, we propose the species be up-listed from 'Vulnerable' to 'Endangered'. Total forest cover at Mount Moco in forest patches $>0.5$ ha in size is currently 85 ha. This is c. $40 \%$ of the total cover of Afromontane forest estimated for Angola in 1974. Remaining forest cover at Mt Moco is being eroded by bush fires, removal of wood for fire and construction material, and clearance for subsistence agriculture by the c.330 inhabitants of Kanjonde village. In order to preserve the forest of Mt Moco, we propose the implementation of a protected area and define its boundaries. A similar proposal was made in 1974 for the creation of the Mount Moco Special Reserve.

\section{Resumo}

As florestas das terras altas de Angola formam o menor e mais isolado dos centros de endemismo de montanha de África. Estas florestas abrigam uma biodiversidade única. No entanto, em Angola, apesar deste habitat encontrar-se muito fragmentado e ocupar uma área total inferior a 200 ha, nenhuma parcela está protegida. Aqui destacamos a singularidade destas florestas e as ameaças que enfrentam. Em particular, destacamos a importância do Monte Moco para a conservação das aves e descrevemos a posição actual, área e qualidade da floresta que aqui permanece. Sessenta e quatro espécies/sub-espécies endémicas/quase-endémicas e espécies com populações isoladas estão associadas às terras altas de Angola ocidental. Destas, 19 dependem de floresta de montanha e todas elas estão presentes no Monte Moco, onde um total de 233 espécies foram registadas. O Francolim de Swierstra Pternistis swierstrai é a única espécie endémica ameaçada. Em 2009, um 
censo desta espécie foi efectuado em 10 dos 30 fragmentos de floresta do Monte Moco com uma área superior a 0.5 ha. Esta espécie estava presente em sete dos fragmentos visitados, ocorrendo a uma densidade mínima média de 0.95 pares ha $^{-1}$ nos fragmentos com áreas superiores a 1 ha. A partir deste valor, estimamos um mínimo de 75 pares de Francolim de Swierstra no Monte Moco, e um total mundial de $185-420$ pares. Propomos que o estatuto de conservação desta espécie passe de 'Vulnerável' a 'Em Perigo' devido à sua pequena área de ocorrência e ao tamanho reduzido da sua população. A área total de floresta presente em fragmentos de área superior a 0.5 ha no Monte Moco é de 85 ha. Isto representa cerca de $40 \%$ da área total de floresta de montanha estimada para Angola em 1974. As florestas que restam no Monte Moco estão ameaçadas pelo fogo, pela colheita de madeira para construção e lenha e pela extensão dos campos agrícolas. Estas pressões são exercidas por um única comunidade, a aldeia de Kanjonde com cerca de 330 habitantes. Para salvaguardar as florestas do Monte Moco propomos a implementação de uma área protegida e definimos as suas fronteiras. Uma recomendação similar já tinha sido feita em 1974 com a proposta da criação da Reserva Especial do Monte Moco.

\section{Introduction}

The highlands of west-central Angola are of great biogeographical interest, as they contain the most isolated forests of all Afromontane centres of endemism (White 1981, 1983), separated by $>2,000 \mathrm{~km}$ from other, similar habitats (Huntley 1974). This isolation has allowed the development of plant and animal communities that are quite distinct from those of other montane centres (White 1978, Grimshaw 2001). Understanding how and when the fauna and flora of these isolated mountains were linked with those of other African montane areas and between isolated pockets within the Angolan montane region has the potential to bring new insights into the history of the entire Afromontane centre of endemism. Climate-associated cycles of forest expansion and contraction (Maley 1991, 1996) have played a major role in species diversification in Africa, as has been demonstrated for the avifauna of the East African mountains (Fjeldsa and Bowie 2008). The Angolan montane avifauna appears to reflect similar cycles of connection and isolation from other montane centres (Hall 1960, Huntley 1974, Dean 2000). Bird species that may have been widespread during periods that favoured the extension of montane-like forest are now restricted to small 'islands' of suitable conditions in the Angolan highlands. These isolated populations span the entire continuum of the speciation process: (i) isolated but undifferentiated populations, such as African Olive Pigeon Columba arquatrix; (ii) phenotypically divergent populations currently classified as endemic subspecies, like the gadowi subspecies of Bronzy Sunbird Nectarinia kilimensis; and (iii) full species, like the Angola Slaty Flycatcher Dioptrornis brunneus, with their nearest relatives found in distant highland areas of the Cameroon Mountains, Albertine Rift or Eastern Arc Mountains.

Afromontane forest is the most localised habitat type in Angola, being naturally restricted to narrow gorges and steep mountain valleys of the highest peaks, typically above 2,00o $\mathrm{m}$ altitude (Collar and Stuart 1988, Huntley and Matos 1994). In the 1970s, Afromontane forest occurred in a few isolated patches in the high-lying areas of the provinces of Huambo, Benguela, Cuanza Sul and Huila. At that time the 'best examples' were found at Angola's highest mountain, Mt Moco, Huambo province (centred on $12.448^{\circ} \mathrm{S} 15.189^{\circ} \mathrm{E}, 2,620 \mathrm{~m}$ ), where there were 15 or more patches of $1-20$ ha in size (Huntley 1974), but totalling $<100$ ha (Huntley 1978). There was a similar area of forest at Mt Namba (11.858 $8^{\circ} \mathrm{S} 14.758^{\circ} \mathrm{E}$; B. Huntley pers. comm.), although these forests had been exploited for timber with no pristine patches remaining in the 1970 (Huntley \& Matos 1994). Including small patches from other scattered localities, such as Mombolo (12.195 ${ }^{\circ} \mathrm{S}$ 14.870 $\mathrm{E}$; AOo18) and Tundavala $\left(14.817^{\circ} \mathrm{S} 13.381^{\circ} \mathrm{E} ;\right.$ AOo23; Dean 2001), Huntley (1974) estimated an area of $<200$ ha of Afromontane forest in total, but possibly underestimated the area of forest on Mt Namba. Among the birds dependent on these forests are three rangerestricted species, namely Swierstra's Francolin Pternistis swierstrai ('Vulnerable'), Angola Slaty 
Flycatcher and Ludwig's Double-collared Sunbird Cinnyris ludovicensis (Stattersfield et al. 1998, BirdLife International 2009).

Since the early 1970s, when the status of these restricted-range birds was last investigated (see Ryan et al. 2004), it is likely that forest condition and cover have declined. The few remaining forest patches are vulnerable to fire and clearance for subsistence agriculture (Dean 2001), and are being fragmented, reduced in size from the valley-bottoms up and selectively logged of large trees (pers. obs.). Extensive exploration of areas of Angola above 2,000 m altitude based on evidence from Google Earth (2009) confirms that currently only Mt Moco and Mt Namba hold significant patches of forest. The Tundavala area near Lubango holds a total of c.2o ha of forest. Despite the threats outlined above, the limited extent and global biological importance of these forests (Stattersfield et al. 1998, Burgess et al. 2004), and a long-standing proposal for a Mt Moco Special Reserve (Huntley and Matos 1994), these forests are currently entirely unprotected, putting them at risk of becoming the first montane centre of endemism to be lost on the continent (Huntley 1974).

In reporting here on some recent studies in the Angolan highlands, preliminary to a concerted drive to conserve their few remaining patches of Afromontane forest, we (i) highlight priority bird taxa of the Angola highlands for phylogenetic investigation (in its broadest sense) and conservation, (ii) outline the avifauna of the proposed Mt Moco Special Reserve, (iii) assess the status of Swierstra's Francolin at Mt Moco and reassess its Red List status, (iv) define the current position, extent and condition of Afromontane forest at Mt Moco, and, based on this, (v) recommend exact boundaries for the proposed conservation area and make practical recommendations for the conservation of these forests.

\section{Methods}

Study area

Mt Moco is situated in the Marginal Mountain Chain of Angola on residual land surfaces of Gondwana age (see Huntley 1974). The mountain itself rises steeply to 2,300-2,600 m from a gently undulating plateau incised by many narrow watercourses at $1,600-1,900 \mathrm{~m}$. Rainfall is within the $1,400 \mathrm{~mm}$ isohyet (Silveira 1967). Open grasslands with widely scattered trees and shrubs cover large parts of the area, both on the mountain massif and north-west across the plateau to the town of Ussoque $\left(12.353^{\circ} \mathrm{S} 15.100^{\circ} \mathrm{E}\right.$; Fig. 1). In well-drained areas, this vegetation is generally fire-prone and includes shrub species such as Philippia benguelensis, Erica spp., Protea trichophylla, Stoebe vulgaris and Cliffortia spp., and grasses Themeda triandra, Tristachya inamoena, T. bequertii, Hyparrhenia andongensis, H. quarrei, Festuca spp. and Monocymbium ceresiiforme (Huntley and Matos 1994). Xerophyta sp. shrubs are common on rocky outcrops. The grasslands in the ecoregion are partly of edaphic origin and partly maintained by fire, much of this probably of anthropogenic origin. Most of the northern, eastern and southern flanks and adjacent areas of the mountain are covered in dense Brachystegia-dominated miombo woodland.

Patches of Afromontane forest are surrounded by grassland and are restricted to ravines on the main mountain massif, particularly on the western and central parts (Fig. 2). One of the characteristic tree species commonly present prior to 1970 was Podocarpus latifolius/milanjianus, and other common trees were Polyscias fulva, Apodytes dimidiata, Pittosporum viridiflorum, Syzygium guineense afromontanum, Halleria lucida, Ficus spp., Olea spp. and Ilex mitis (Huntley and Matos 1994). These forests showed fewer epiphytes (mostly ferns and mosses) than similar forests elsewhere in Africa and hardly any grass grew in intact patches. The canopy tended to be very irregular because of the steep and rocky slopes on which the forest patches are found. Currently, dense growth of the largest trees occurs only in the remotest parts of the mountain, often high up in steep ravines. However, few Podacarpus trees can be found in the forest patches within $3 \mathrm{~km}$ of Kanjonde village (12.428 $8^{\circ} \mathrm{S} 15.153^{\circ} \mathrm{E}$; pers. obs.). 


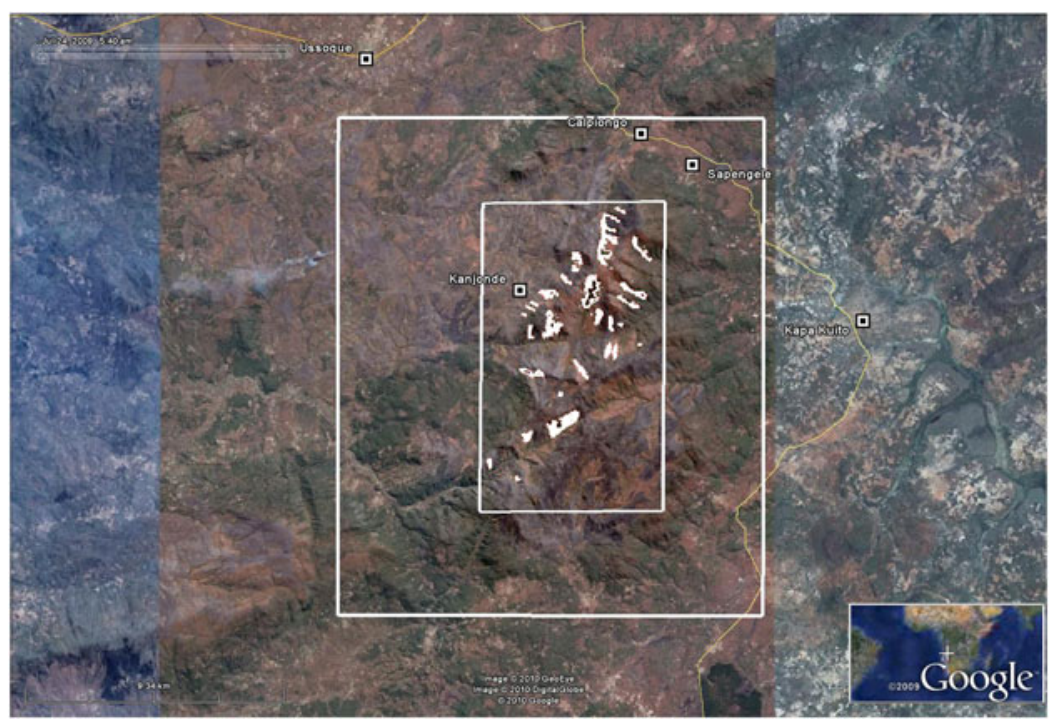

Figure 1. A Google Earth (2009) satellite image of the Mount Moco study area, showing all forest patches $>0.5$ ha in extent as white polygons, and the settlements of Ussoque, Kanjonde, Calpiongo, Sapengele and Kapa Kuito. The inner white rectangle covers c.7,215 ha and includes all current forest cover, whereas the larger rectangle, which we propose forms the boundaries of a conservation area, covers c.27,00o ha of Afromontane forest, Brachystegia woodland and montane grassland, and would allow for the expansion of montane forests towards their previous extent. These areas are bounded, respectively, by the points $12.400^{\circ} \mathrm{S} 15.140^{\circ} \mathrm{E}$ in the north-west and $12.500^{\circ} \mathrm{S} 15.200^{\circ} \mathrm{E}$ in the south-east, and $12.373^{\circ} \mathrm{S} 15.092^{\circ} \mathrm{E}$ in the north-west and $12.534^{\circ} \mathrm{S} 15.233^{\circ} \mathrm{E}$ in the south-east.

\section{Avifauna}

In order to identify bird taxa associated with the Angolan highlands that are priorities for conservation, we used the Birds of Africa series, Dean (2000) and Sinclair and Ryan (2003) to evaluate all montane bird taxa occurring in the region. Taxa were evaluated qualitatively, according to the following criteria: (I) degree of distributional association with highlands of the Western Angola EBA: (1a) more-or-less confined to it ( $>90 \%$ distributional overlap) or $(\mathrm{Ib})$ associated with it, although more widespread $(75-90 \%)$; (2) habitat preference: (2a) forest, including forest edge and rank growth in gullies, or (2b) non-forest; and (3) endemism: (3a) Angolan endemic or near-endemic species, ( $3 b)$ endemic subspecies or (3c) taxon with isolated population. Since forests are the most threatened habitats of the region, forest-dependent taxa are of greatest conservation concern.

We recognise that assignment of taxa to different categories outlined above is based partly on qualitative assessments and subjective interpretation. Highland areas merge gradually into nonmontane habitats, making boundaries of the area, and hence degree of distributional association, hard to define. Moreover, incomplete knowledge of the distribution of taxa, largely due to lack of sampling in eastern Angola, means that several seemingly isolated bird populations may occur continuously with those in western Zambia or other adjacent areas; these taxa are highlighted in Table SI in the online Supplementary Materials. Finally, proper assessment of taxon validity is required in several cases, and attention is drawn to these in Table $\mathrm{S}_{1}$. Despite these shortcomings, we believe the lists will act as a useful starting point that can be refined as knowledge improves. 


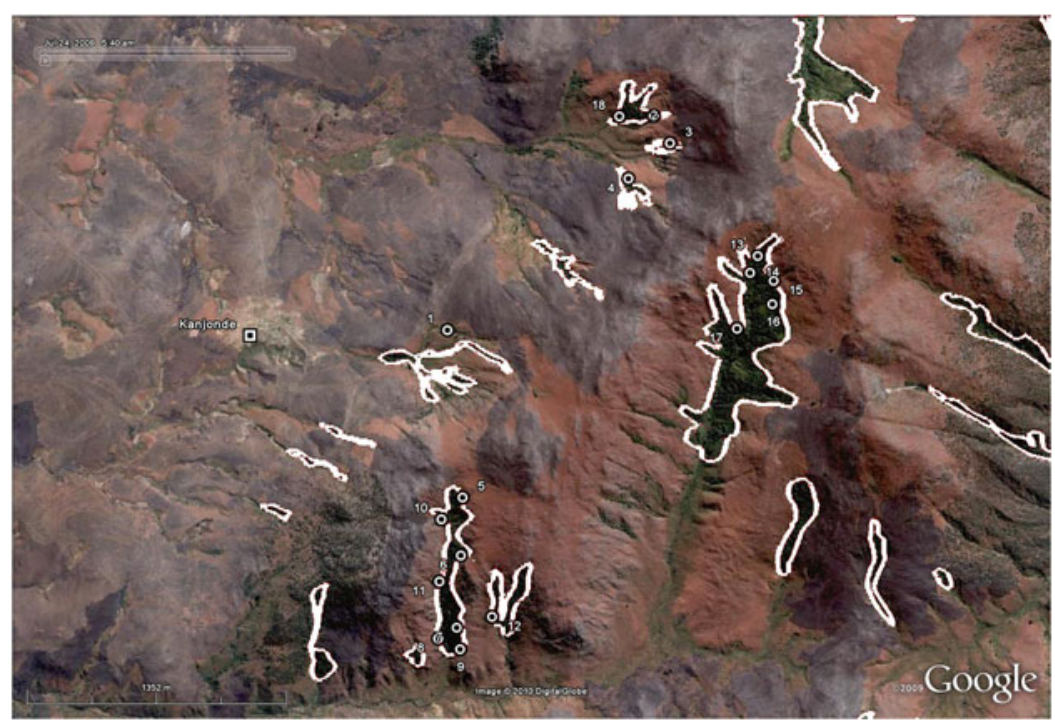

Figure 2. A Google Earth (2009) satellite image of the central part of the Mount Moco study area, showing the location of our 18 records of Swierstra's Francolin. Forest patches are bordered by white polygons and the village of Kanjonde is visible on the central left of the image.

English and scientific names and taxonomic treatment of birds follow Gill et al. (2009) throughout, and IUCN Red List status is from BirdLife International (2008).

To establish the ornithological importance of the proposed Mt Moco Special Reserve, we present species lists for Mt Moco derived from a database of Angolan bird records (most summarised in Dean 2000, 2001; WRJD unpublished data), records from three groups of observers who visited between 2003 and 2006 (see Appendix $S_{1}$ in the online Supplementary Materials for details; Borrow 2005) and our own records from field visits (details below). We have been conservative in accepting species onto the lists, and several that have been reported to occur have been excluded pending further evidence.

WRJD's database includes records from all the expeditions which collected, inter alia, at Mt Moco. The first of these was by Rudyerd Boulton, who in February 1931 collected for the Carnegie Museum, Pittsburgh (Boulton 1934), followed by the Phipps-Bradley Expedition in 1933 (specimens in the American Museum of Natural History, New York) and Rudolf Braun in April 1934 (some specimens in The Natural History Museum, Tring). Twenty years later, from 14 September to 17 October 1954, Gerd Heinrich collected for both the Field Museum of Natural History, Chicago and the Zoologisches Institut und Zoologisches Museum in Hamburg (Heinrich 1958a,b,c). The British Museum Expedition collected there from 14 to 24 August 1957 (Hall 1960), and most recently Pinto (1983) led a field trip to Mt Moco for the Instituto de Investigação Científica de Angola (IICA) in Lubango from 16 May to 24 June 1964.

We made three different field visits to Mt Moco between 2005 and 2009. During initial explorations, MSLM visited from 11 to 14 August 2005, compiling daily lists of birds observed. In November 2008, MSLM, FO and MM visited the western and central sections of Mt Moco (11-13 November and 18-21 November); daily lists of birds observed were compiled, and birds were mist-netted and genetic samples collected for use in evolutionary studies (see Appendix $\mathrm{S}_{2}$ in the online supplementary materials for a list of taxa). Preparatory work for a community-based conservation programme was initiated with human impacts on habitats noted, and the chief (soba) of Kanjonde village was interviewed about natural resource uses of the community and 
briefed on the value and uniqueness of the forests. Finally, during our most recent visit, MSLM and MM spent seven days at Mt Moco in July/August 2009; daily lists of bird species were again compiled, bird communities of individual forest patches surveyed by standardised 10-minute point counts with a $100 \mathrm{~m}$ radius to assess how bird communities change with decreasing forest size, birds mist-netted and genetic samples collected, and household surveys conducted on natural resource uses for the entire Kanjonde village ( $n=81$ household surveys).

\section{Swierstra's Francolin}

During all three of our visits, special attention was paid to locating Swierstra's Francolin, the most threatened montane endemic. During 2005, locations of sightings ( $n=6$ at Mts Moco/Soque) were recorded with a GPS, and sound recordings were made of male crowing and agitation calls, which were used for playback during searches for this species in 2008 and 2009. In 2005, c.80\% of Mt Soque $\left(12.287^{\circ} \mathrm{S} 15.139^{\circ} \mathrm{E}, 2,165 \mathrm{~m}\right)$ was visited on foot by MSLM, and although at this time there was no longer any Afromontane forest on the mountain, four pairs of Swierstra's Francolin were located there in the only suitable habitat, i.e. dense herbaceous and shrubby growth in gullies and around the mountain summit. Males crowed each morning and evening, and up to three males could be heard crowing simultaneously. Crowing males were spaced 200-350 m apart. Searches at Mt Soque on two consecutive days revealed the same four pairs.

In November 2008, four different forest patches were visited opportunistically at Mt Moco, but playback of Swierstra's Francolin vocalisations failed to elicit any responses. It is not known whether the species calls at this time of the year. Due to limited time, no systematic search was made for the species, and due to high rainfall, flowing forest streams made it impossible to hear francolins walking in the leaf-litter. Locations of the two pairs encountered at the forest edge were recorded using a GPS.

In July/August 2009, 1o different forest patches $>0.5$ ha were searched systematically at $\mathrm{Mt}$ Moco for Swierstra's Francolin (see Table I). All forest patches were generally linear in shape, following a drainage line. Two search strategies were employed to locate francolins: (1) Io-minute point counts spaced every 250-300 m along the forest edge (only single point counts were made in the smaller patches), and (2) walking along the forest edge between points counts. At the start of point counts, 1-2 minutes of male crowing and agitation calls were played to stimulate calling. Whilst walking between point counts, the entire length of one side of the forest edge was searched carefully, listening for francolins walking across the leaf-litter or making agitation calls. When potential francolins were heard in the leaf litter, their identity was confirmed by seeing them or hearing them call. The position of all Swierstra's Francolin was recorded by GPS or mapped. Since all species of southern African francolins typically occur in pairs or small coveys (Hockey et al. 2005), each record was assumed to represent a pair of adult birds.

All surveys were conducted between sunrise and 1oh30, during relatively windless conditions. Males typically crowed between sunrise and 1oh30, after which they became silent and could not be stimulated to crow, and again briefly at sunset. Birds either did not call or could not be heard during windy conditions. Field conditions (time to walk to and between forest patches, and weather) and time available made it impossible to survey all forest patches before 1oh3o. Hence, only the upper $25 \%$ of the largest forest patch (Patch o8) and only one-third of Patch II were surveyed (see Table 1). Surveys were conducted towards the end of the dry season (May-September), when leaflitter was dry and it was easy to hear francolins walking. Furthermore, forest streams were not flowing, so did not reduce our ability to hear francolins walking or vocalising.

\section{Forest cover and condition}

In order to assess spatial distribution of forest patches at Mt Moco, and their sizes, perimeter lengths and condition, we used satellite imagery available on Google Earth (2009). Cloud-free, 
Table 1. A list of forest patches at Mount Moco larger than 0.5 ha, as measured from Google Earth (2009) imagery for June 2004, together with the number of pairs of Swierstra's Francolin found during surveys ("Francolin observed") and expected number of pairs per patch based on average densities. "Perimeter (km)" gives the length of the perimeter of, and "Area (ha)" the area covered by each patch of forest. These measurements were calculated from polygon shape files $(. \mathrm{kmz})$ created for each forest patch by on-screen digitising in Google Earth. "Area/Edge ratio" is calculated as "Area"/"Perimeter". "\% forest" is the visually-estimated percentage of the polygon covered by closed-canopy forest, to the nearest 10\%. "Area of forest" = "Area" x "\% forest".

\begin{tabular}{|c|c|c|c|c|c|c|c|}
\hline Patch & $\begin{array}{l}\text { Perimeter } \\
(\mathrm{km})\end{array}$ & $\begin{array}{l}\text { Area } \\
\text { (ha) }\end{array}$ & $\begin{array}{l}\text { Area/Edge } \\
\text { ratio }\end{array}$ & $\%$ forest & $\begin{array}{l}\text { Area of } \\
\text { forest (ha) }\end{array}$ & $\begin{array}{l}\text { Francolin } \\
\text { observed }\end{array}$ & $\begin{array}{l}\text { Francolin } \\
\text { expected }\end{array}$ \\
\hline OI & 0.74 & 0.68 & 0.9 & 90 & 0.6 & $\mathrm{o}$ & o \\
\hline $\mathrm{O} 2$ & 0.67 & 0.52 & 0.8 & 50 & 0.3 & $\mathrm{o}$ & $\mathrm{o}$ \\
\hline 03 & 3.14 & 4.04 & 1.3 & 30 & 1.2 & 1 & $I$ \\
\hline $\mathrm{O} 4$ & 1.23 & 2.77 & 2.3 & 90 & 2.5 & 1 & 2 \\
\hline 05 & 0.34 & 0.57 & 1.7 & 90 & 0.5 & 1 & O \\
\hline 06 & 0.99 & 1.30 & 1.3 & 80 & 1.0 & 1 & 1 \\
\hline 07 & 9.08 & 27.57 & 3.0 & 30 & 8.3 & no survey & 8 \\
\hline o8 & 4.92 & $23 \cdot 34$ & 4.7 & 80 & 18.7 & ${ }^{* *} 4$ & 18 \\
\hline 09 & 2.20 & 8.47 & $3 \cdot 9$ & 80 & 6.8 & 7 & 7 \\
\hline 10 & 1.31 & 1.61 & 1.2 & 50 & 0.8 & o & o \\
\hline 11 & 1.53 & $3 \cdot 53$ & 2.3 & 90 & 3.2 & $* * 1$ & 3 \\
\hline 12 & 1.19 & 4.29 & 3.6 & 100 & $4 \cdot 3$ & no survey & 4 \\
\hline 13 & 1.25 & 2.36 & 1.9 & 90 & 2.1 & no survey & 2 \\
\hline 14 & 2.46 & 7.95 & 3.2 & 70 & 5.6 & no survey & 5 \\
\hline 15 & 2.08 & 4.57 & 2.2 & 80 & $3 \cdot 7$ & no survey & 3 \\
\hline 16 & 1.06 & $3 \cdot 38$ & 3.2 & 90 & 3.0 & no survey & 3 \\
\hline 17 & 0.43 & 0.59 & 1.4 & 50 & 0.3 & no survey & $\mathrm{o}$ \\
\hline 18 & 1.19 & 2.41 & 2.0 & 50 & 1.2 & no survey & 1 \\
\hline 19 & 2.66 & 8.10 & 3.0 & 50 & 4.1 & no survey & 4 \\
\hline 20 & 0.31 & 0.53 & 1.7 & 70 & 0.4 & no survey & o \\
\hline 21 & 2.35 & 4.20 & 1.8 & 50 & 2.1 & no survey & 2 \\
\hline 22 & 0.89 & 1.26 & 1.4 & 70 & 0.9 & no survey & o \\
\hline 23 & 1.93 & $3 \cdot 48$ & 1.8 & 30 & 1.0 & no survey & 1 \\
\hline 25 & 0.34 & 0.60 & 1.8 & 70 & 0.4 & no survey & o \\
\hline 26 & 1.22 & 2.22 & 1.8 & 70 & 1.6 & no survey & 1 \\
\hline 27 & 0.44 & 0.64 & 1.5 & 70 & 0.4 & no survey & $\mathrm{o}$ \\
\hline 28 & $7 \cdot 70$ & 13.37 & 1.7 & 50 & 6.7 & no survey & 6 \\
\hline 29 & 1.65 & 3.99 & 2.4 & 60 & 2.4 & no survey & 2 \\
\hline 30 & 0.43 & 0.89 & 2.1 & 40 & 0.4 & no survey & o \\
\hline 31 & 0.81 & 1.72 & 2.1 & 60 & 1.0 & no survey & 1 \\
\hline Total/Average & $\mathrm{T}=56.54$ & $\mathrm{~T}=140.95$ & $A=2.1$ & $A=66$ & $\mathrm{~T}=85.0$ & $\mathrm{~T}=16$ & $\mathrm{~T}=75$ \\
\hline
\end{tabular}

* note that forest patch 24 was digitised but found to be smaller than 0.5 ha, so is omitted from this list.

**incomplete survey or surveyed during sub-optimal conditions

high-resolution images from June 2004 are available for the entire mountain; data presented herein, based on these images, should be used as a baseline for future studies. Using on-screen digitising we created a. $\mathrm{kmz}$ polygon file for all forest patches larger than 0.5 ha. Defining individual forest patches was complicated by the proximity of two or more patches of forests that were clearly previously continuous along the same drainage line. Generally, where forest patches forming part of the same drainage line were separated by more than $100 \mathrm{~m}$ they were treated as different patches. The Google Earth (2009) "measuring tool" was then used to determine the perimeter/edge length $(\mathrm{km})$ and area (ha) of each of these patches, and results used to calculate an edge/interior ratio. The percentage of closed-canopy forest cover (as opposed to scattered trees, 
shrubbery or bracken beds) within each patch was visually estimated to the nearest $10 \%$, to calculate the amount of forest in each patch.

\section{Results}

\section{Priority taxa of the highlands of western Angola}

We identified 64 bird taxa that meet the criteria of being endemic or near-endemic species, endemic subspecies or isolated populations that are associated with the highland areas of western Angola (Table Si). Nineteen of the 64 taxa are associated with Afromontane forest, including rank growth at forest edge and in gullies. Swierstra's Francolin is the only threatened species endemic to the highlands of Angola and is thus the top priority for conservation. Angola Slaty Flycatcher and Ludwig's Double-collared Sunbird are the only other endemic species associated with forest, although they are not restricted to this habitat. A further eight forest species have subspecies endemic to the highlands of western Angola.

The remaining 45 taxa occur in non-forest habitats such as grassland, miombo woodland and papyrus swamps. Only Wattled Crane Grus carunculatus is listed as threatened, although the endemic Angola Cave Chat is 'Near Threatened'. Also of importance is the near-endemic Bocage's Sunbird Nectarinia bocagii, found outside central Angola only in adjacent Democratic Republic of Congo. The distinctive bocagei subspecies of Swee Waxbill Estrilda melanotis is probably deserving of specific status (Mills and Dean 2007), as may be the leucogaster subspecies of White-headed Barbet Lybius leucocephalus (Pinto 1983) and bailunduensis subspecies of Rock-loving Cisticola Cisticola emini; the last has distinctively different vocalisations from other forms in the emini/aberrans group (pers. obs.). The taxonomic status of these taxa needs to be re-evaluated as a matter of priority.

\section{The avifauna of Mt Moco}

A total of 233 birds species has been recorded at Mt Moco (Appendix SI), slightly more than the 221 listed by Dean (2001). These include approximately 35 species restricted to forest and many montane species, such as Bar-tailed Trogon Apaloderma vittatum, Ruwenzori Nightjar Caprimulgus ruwenzorii, Angola Lark Mirafra angolensis, Laura's Woodland Warbler Phylloscopus laurae, Orange Ground Thrush Zoothera gurneyi and Yellow-crowned Canary Serinus flavivertex. In addition, several other species not listed in Appendix $\mathrm{S}_{1}$ have been reported to occur, but require confirmation before being accepted. There is only one unsubstantiated report of Red-crested Turaco Tauraco erythrolophus from Mt Moco (Sinclair et al. 2004), a species previously only known from subtropical forest and unlikely to occur there. Other species reported but which require confirmation include Red-winged Francolin Scleroptila levaillantii, Blue Quail Excalfactoria adansonii, Black-rumped Buttonquail Turnix nanus, Brown-backed Honeybird Prodotiscus regulus and Stout Cisticola Cisticola robustus. Moreover, there is no conclusive evidence for the occurrence of several species summarised in the lists of Dean (2000, 2001); here we treat them as unconfirmed. These include Arnot's Chat Myrmecocichla arnotti, Brown Firefinch Lagonosticta nitidula, Vieillot's Black Weaver Ploceus nigerrimus and Cinderella Waxbill Estrilda thomensis. Specimens of White-bellied Sunbird Cinnyris talatala from this area were re-examined in the Field Museum of Natural History and were found to be misidentified Oustalet's Sunbird C. oustaleti (D. Willard and J. Bates pers. comm.); Whitebellied Sunbird is unlikely to occur in the area (Dean 2000). Dickinson's Kestrel Falco dickinsoni has been recorded some $30 \mathrm{~km}$ to the north (Dean 2000), but its local occurrence within the IBA requires confirmation. Cassin's Honeybird Prodotiscus insignis is reported from the mountain, but this should be corrected to Green-backed Honeybird P. zambesiae because of changes in taxonomy (see Mills and Dean 2007). Most importantly, due to databasing errors, the 'Data Deficient' Grimwood's Longclaw Macronyx grimwoodi was reported to be common in the area 
(Dean 2001), but there are no records of this species from Mount Moco (WRJD unpublished database).

\section{Swierstra's Francolin}

For each of the 10 forest patches surveyed, a minimum density (pairs ha ${ }^{-1}$ ) of Swierstra's Francolin was calculated from the number of pairs of francolin found, divided by the area of forest (ha; Table 1 ). The mean minimum density of Swierstra's Francolin was calculated across all forest patches with francolins $(n=7)$. Of the four patches smaller than 1 ha surveyed, only one yielded a single pair of Swierstra's Francolin, which may not have been resident in this patch. To calculate the minimum population size of Swierstra's Francolin at Mt Moco we extrapolate the mean minimum density of 1 pair ha ${ }^{-1}$ (rounded from 0.95 pair ha $^{-1}$ ) to all forest patches $>1$ ha in size (see Table 1 ).

All 18 groups of Swierstra's Francolin recorded during our three field visits to Mt Moco were recorded from forest, forest edge or rank growth in gullies, with only one pair venturing marginally into the adjacent rank grassland (Fig. 2). During 2009, we found 16 pairs of Swierstra's Francolin distributed across seven of 10 surveyed forest patches $>0.5$ ha in size, at a mean minimum density of $0.95 \pm 0.489$ pairs ha ${ }^{-1}$ (mean $\pm \mathrm{SD}$ ). An insufficient sample size from point counts makes it impossible to estimate detection rates, so data are used to calculate only minimum densities. However, francolin rarely occur at densities $>1$ pair ha ${ }^{-1}$ (Hockey et al. 2005), so these are likely to be reasonably accurate estimates. This mean minimum density is rounded to I pair ha ${ }^{-1}$ and extrapolated to a minimum population size of 75 pairs of Swierstra's Francolin at Mt Moco (see Table 1).

Assuming that (i) Angola has 200 ha of Afromontane forest (Huntley 1974), (ii) $95 \%$ of Swierstra's Francolin are found associated with Afromontane forest (four pairs in this study were outside forest, at Mt Soque), (iii) Mt Moco holds the same proportion of the population of Swierstra's Francolin as it does Afromontane forest (42.5\%, 85 ha of 200 ha), and (iv) there is a population of 75 pairs of francolin at Mt Moco, we estimate a minimum global (meaning total, world-wide) population of 185 pairs. This is calculated as: ([75 pairs at Mt Moco] / [0.425, the proportion of Angolan Afromontane forest at Mt Moco]) + [5\% additional pairs not in forest]. As an upper estimate, if we extrapolate the highest published density estimate ( 2 pairs ha ${ }^{-1}$; BirdLife International 2008) across 200 ha of forest, and assuming $95 \%$ of francolins are found in Afromontane forest, we estimate a maximum global population 420 pairs. Hence, we estimate a global population of $185-420$ pairs.

\section{Forest quantity and anthropogenic threats}

Based on field surveys and Google Earth imagery, there are 30 forest patches larger than 0.5 ha at Mt Moco (Table 1). However, only five are $>5$ ha and one $>10$ ha (Patch o8; locally called the Luanda forest, 18.7 ha of forest). The total forest area in patches $>0.5$ ha at Mt Moco is 85 ha (Table 1 ). These forests are bounded by a rectangular area of c.6.5 $\times 11.1 \mathrm{~km}(7,215 \mathrm{ha})$, although previously forest would have extended down the main river valleys over a much larger area (Fig. 1). Hence only $1.2 \%$ of the central area of Mt Moco is covered in forest, with the rest covered in grassland and woodland. This is in stark contrast to the estimate of $95 \%$ forest cover of BirdLife International (2009). All patches are long and narrow in shape, and hence have small area-to-edge ratios. Moreover, all forest inspected visually showed sign of human disturbance, including logging of large trees and evidence of fire penetrating into the forest understorey.

The number of people living in the study area is relatively small, with only one village located near enough to the mountain for inhabitants to use forest resources. This is the village of Kanjonde, with c.330 inhabitants (250 adults; soba pers. comm.). There was little evidence of hunting during our visits, although mammals appeared to be almost extinct in the area. Of much 
greater threat to the conservation of birds at Mt Moco is unsustainable utilisation of wood, clearing of forest for subsistence agriculture, and deliberate burning of vegetation. The village of Kanjonde has no power supply, and all cooking is done on fuel wood collected from the nearby forests and miombo woodland. The soba of Kanjonde confirmed that the village had been on the edge of a patch of montane forest in 1922, at the time of his birth, whereas now the nearest patch of forest trees was at least $500 \mathrm{~m}$ away; an old Ficus tree in the middle of the village is the only testament to this. Between our two visits in 2005 and 2008 one of the larger forest patches at $\mathrm{Mt}$ Moco, near the village of Kanjonde, was visibly reduced in size, and a fire in 2008 burned at least 2 ha of forest that was relatively intact in 2005. All forest patches inspected in 2008 showed signs of recent burning at the edge. The lower valleys of Mt Moco are almost entirely cultivated, with all trees being removed. Large tracks of miombo woodland are also being felled to make way for crop cultivation, and trees are being used as firewood and for production of charcoal. Anthropogenic bush fires are also of concern. Grasslands are burned annually, with fires burning back the forest edges and sometimes entering the interior of forest patches. Furthermore, inhabitants of Kanjonde light fires within forest patches to clear the understorey to make access for wood removal easier, and later come to collect dead trunks and branches.

\section{Discussion}

We highlight priority taxa of the Angolan highlands, which include endemic and near-endemic species and subspecies, and isolated populations. Amongst these are several taxa poorly known in Angola, being recorded from only three or fewer localities. Any records of these species are significant: Rufous-breasted Sparrowhawk Accipiter rufiventris, Ruwenzori Nightjar, Scarce Swift Schoutedenapus myoptilus, Fernando Po Swift Apus sladeniae, Bar-tailed Trogon, Orange Ground Thrush, Evergreen Forest Warbler Bradypterus lopezi, Pale-crowned Cisticola Cisticola cinnamomeus, Laura's Woodland Warbler, Margaret's Batis Batis margaritae, Black-chinned Weaver Ploceus nigrimentus and Thick-billed Seedeater Crithagra burtoni.

The only site in Angola from which all forest-dependent priority taxa (Table $\mathrm{S}_{1}$ ) have been recorded is Mt Moco, making it the most important in Angola for the conservation of Afromontane forest avifauna. Dean (2001) lists five species occurring only at Mt Moco within Angola. These are Scarce Swift, Fernando Po Swift (Brooke 1970), Ruwenzori Nightjar, Bar-tailed Trogon and Margaret's Batis. In addition, Orange Ground Thrush is also found only here, and Laura's Woodland Warbler only here and at Chipepe (Mills and Dean 2007). The nightjar, however, is more widespread, as may be both swifts (Mills and Dean 2007, Mills 2009). It should be noted that Margaret's Batis is known only from Mt Moco, since Serra do Mange ('Sando do Monge' in Mills and Dean 2007) is a synonym for Mt Moco. Dean (2001) and BirdLife International (2009) also list the nigricauda subspecies of Mountain Wheatear Oenanthe monticola as endemic to the mountain, but it has now been recorded as far north as the Gabela area (Mills and Dean 2007).

Most of the 19 priority taxa associated with forest (Table SI) still occur at Mt Moco, although there is only one recent record of Laura's Woodland Warbler (see Appendix S1). Bar-tailed Trogon (Hall 1960) and Orange Ground Thrush (Heinrich 1958b), collected at Mt Moco in 1950s, are yet to be re-found, despite playback of vocalisations at suitable habitat to stimulate singing. However, these are inconspicuous species, and more thorough surveys are required. One conspicuous forest species that has not been found during our surveys is Naked-faced Barbet Gymnobucco calvus vernayi (Hall 1960). This species may have disappeared from Mt Moco, although the same subspecies is regular along the Angolan scarp (Mills in press).

Mt Moco is also important because it holds the only known viable population of Swierstra's Francolin, currently listed as 'Vulnerable'. All previous records of the species were summarised by Mills (2007) although, due to unclear labelling, there was some uncertainty surrounding the exact details of the skins in the Lubango Bird Skin Collection. The corrected data are presented in Table 2 and were verified during a visit to Lubango in June 2008 (Mills et al. 2010); the most 
Table 2. Specimens of Swierstra's Francolin in the Lubango Bird Skin Collection.

\begin{tabular}{lllll}
\hline Specimen No. & Date & Locality & Sex & Collector \\
\hline 10529 & $1965-02-11$ & Tundavala & Female & F. Nobrega \\
10530 & $1965-02-11$ & Tundavala & Male & F. Nobrega \\
21995 & $1968-03-25$ & Tundavala & Female & A. R. Pereira \\
22305 & $1968-04-25$ & Tundavala & Female & A. R. Pereira \\
35122 & $1971-08-31$ & Cariango & Female & J. Carlos \\
35123 & $1971-08-31$ & Cariango & Female & J. Carlos \\
\hline
\end{tabular}

recently collected specimen dates from 31 August 1971. Besides records from Mts Moco/Soque, the species is known from four specimens from Tundavala, one from Hanha, one from Mombolo and two from Cariango (see Mills 2007 for details on localities). Current population sizes from these four sites are unknown, as there are no recent records. A visit to the Mombolo area in 2005 indicated that the area is heavily land-mined, making it impossible to conduct surveys. Furthermore, Google Earth (2009) imagery revealed no significant forest cover here, or at Hanha and Cariango, which have not yet been visited. In January 2009 MSLM spent four days searching for the species in suitable habitat in the vicinity of Tundavala/Lubango, visiting four different patches of Afromontane forest. No birds were found there, despite knowledge of the species's calls, and playback being used to stimulate calling, in order to increase rate and reliability of detection (Parker 1991, Boscolo et al. 2006), so it is unlikely that there are many birds there.

Besides Mount Moco, the only other locality likely to hold a significant population of Swierstra's Francolin is Mt Namba. Recent (2009) Google Earth images show 300-400 ha of suitable habitat for Swierstra's Francolin on Mt Namba. This area has not been surveyed for birds, nor have the nature, condition and extent of the forest patches been quantified. If Mt Namba holds as much as 400 ha of forest, and Angola 500 ha in total, these extrapolated figures would increase the estimated population of Swierstra's Francolin to 462-1,050 pairs.

The previous population estimate for this species, of $3,700-7,400$ birds (BirdLife International 2008), is much larger than our estimate of $185-420$ pairs, or the estimate of $462-1,050$ pairs if $\mathrm{Mt}$ Namba holds 400 ha of forest. In reality, much less than the estimated 10\% of the Extent of Occurrence is covered in suitable habitat. For 'Vulnerable' species, the term 'Extent of Occurrence' relates to geographic range and incorporates a number of factors, including (inter alia) a fragmented range of less than $20,000 \mathrm{~km}^{2}$, declining populations and fluctuations in demography (see IUCN Red List Criteria in BirdLife International 2008). Swierstra's Francolin is a habitat specialist, confined to Afromontane forest and rank growth on the highest mountain peaks, of which 200-500 ha remains in Angola. Because the species is known from several isolated but widely scattered localities, Extent of Occurrence $\left(18,500 \mathrm{~km}^{2}\right.$; BirdLife International 2008) fails to capture the threat this species faces. Furthermore, due to the nature of the habitat in which the species occurs (narrow, isolated strips of forest and rank growth), Area of Occupancy is similarly inadequate. The Area of Occupancy for 'Vulnerable' species relates to local density of species and takes into account fragmented geographic ranges, declining populations and fluctuations in demography (see IUCN Red List Criteria in BirdLife International 2008). Eleven $2 \times 2 \mathrm{~km}$ cells hold suitable habitat at Mount Moco, giving an Area of Occupancy of $44 \mathrm{~km}^{2}$ where only 85 ha of forest exists. Based on the assumption that Mt Moco holds $42.5 \%$ of suitable habitat, total Area of Occupancy is extrapolated to $104 \mathrm{~km}^{2}$, when only 200-500 ha of suitable habitat exists.

Based on data presented here, we recommend listing of Swierstra's Francolin as 'Endangered'. With an Area of Occupancy of $104 \mathrm{~km}^{2}$, Swierstra's Francolin qualifies under Criterion B2, having an Area of Occupancy of $<500 \mathrm{~km}^{2}$, for Endangered species status (IUCN 2001). The 
subcriteria met are $\mathrm{B}_{2} \mathrm{a}$, having a severely fragmented range, and $\mathrm{B}_{2} \mathrm{~b}$, of having a continued decline inferred from diminishing area and condition of Afromontane forest. Swierstra's Francolin also qualifies as Endangered based on small population size (185-420 pairs) of fewer than 2,500 mature birds. Sub-criterion C2a(i), no subpopulation containing more than 250 mature individuals, is met. Even if Mt Namba proves to hold 400 ha of suitable habitat, this criterion is still met, with an estimated population of $462-1,050$ pairs. However, with less than 500 ha of suitable habitat remaining we believe that the level of threat this species faces justifies listing as 'Critically Endangered', and recommend that Red List assessments should include a criterion based on area of suitable habitat.

Currently, Mt Moco can be regarded as the single most important site in Angola for bird conservation. A whole suite of species rely on these forests for their existence. As a priority, more extensive field surveys incorporating expertise on other taxonomic groups should be undertaken to provide a broader evaluation of the biological importance of Mt Moco. Moreover, exploration, mapping and survey of forests at Mount Namba are needed urgently to provide a complete context for assessing the importance of Mt Moco to Angolan Afromontane forest conservation.

Given the small amount of forest remaining and the widespread influence of humans on the $\mathrm{Mt}$ Moco environment, we urge that this site be formally proclaimed as a protected area as a matter of extreme urgency. The proposed Mt Moco Special Reserve (Huntley 1974) covers an area of c.6,000 ha (Dean 2001) and includes most of the remaining forest on the mountain (see Fig. 1). We propose a formal conservation area with two zones recognised: (i) an inner core area of c.7,215 ha, which includes all current montane forest, to be treated as a 'non-use' zone for natural resources where no new human activities may be initiated, and (ii) a larger buffer zone bounding an area of c.27,00o ha $(15.2 \times 17.8 \mathrm{~km})$, which would conserve Brachystegia woodlands, montane grasslands and montane forests, and allow for expansion of forest towards its previous extent. These areas are bounded, respectively, by the points $12.400^{\circ} \mathrm{S} 15.140^{\circ} \mathrm{E}$ in the north-west and $12.500^{\circ} \mathrm{S} 15.200^{\circ} \mathrm{E}$ in the south-east, and $12.373^{\circ} \mathrm{S} 15.092^{\circ} \mathrm{E}$ in the north-west and $12.534^{\circ} \mathrm{S}$ $15.233^{\circ} \mathrm{E}$ in the south-east (see Fig. I).

To be successful, any conservation project at Mt Moco will need to incorporate needs of people living within the area, which will require a degree of flexibility in both the boundaries and the management of the area. Fortunately the only village reliant on the natural resources of $\mathrm{Mt} \mathrm{Moco}$ is Kanjonde, although surrounding communities should also be included in conservation measures. The villages of Calpiongo and Sapengele are located marginally within the northeast of the larger conservation area outlined above. A key aim of a conservation area should be to work with people to minimise their impacts on habitats, especially by reducing reliance on wood of forest trees, stopping further clearance of forest for agriculture, and reducing the frequency of human-lit bush fires. This can be done by providing alternative sources of wood for building and fire, improving agricultural methods and a programme of environmental education and awareness. Since the area has spectacular scenery, natural beauty, a pleasant climate, and great hiking, mountaineering and birdwatching (Sinclair et al. 2004, Cohen et al. 2006), ecotourism involving the community can also be encouraged to provide direct benefit from preserving the habitat adjacent to which they live. At the same time, restoration of forest by active planting of native trees (such as Trema, Olea and Podocarpus) may be needed to ensure the long-term survival of Afromontane forest at Mt Moco.

\section{Supplementary Material}

The supplementary materials for this article can be found at journals.cambridge.org/bci

\section{Acknowledgements}

We thank all the members of the village of Kanjonde, and especially the soba/chief for allowing us to stay at and work in their village. The administrator of Ussoque was also supportive of our 
work and is thanked for his assistance. José Dala, Feliciano Tchalo and Francisco Maiato assisted with field work and household surveys during the 2009 field trip. MSLM wishes to thank Conservation International (especially Michael Hoffman and Olivier Langrand), and Gus, Margie and Sybil Mills for funding his 2005 field trip. Callan Cohen of Birding Africa and Henk and Diane Burger of Wings over Africa kindly provided logistical support during this visit. Funding for the 2008 and 2009 field trips comes from the generosity of Mr Tasso Leventis of the A. P. Leventis Ornithological Research Institute, and The Rufford Small Grants Foundation. Thanks to Phil Hall and Nigel Collar for their support of this work. Ecovisão Angola provided logistic support in 2008: a special thank you the Pedro Martins, Nádia Marques, Juarez Bongo and Aimy Cáceres for all their support and assistance. Nik Borrow, Adam Riley and Rod Cassidy provided unpublished records of birds from their visits to the area. Nigel Collar and an anonymous referee helped improve the manuscript greatly with their detailed comments. Jez Bird and Andy Symes assisted with information on threatened species assessments. Finally, we thank the Environment Ministry of Angola and Brian Huntley for their support of this work.

\section{References}

BirdLife International (2008) Threatened birds of the world 2008. CD-ROM. Cambridge, UK: BirdLife International.

BirdLife International (2009) Important Bird Area factsheet: Mount Moco, Angola. Downloaded from the Data Zone at http://www.birdlife.org on 28/9/2009.

Borrow, N. (2005) Angola, 22 November-14 December 2005, Tour report. Unpublished report. Available: http://www.birdquest.co.uk (accessed 30/4/2006).

Boulton, R. (1934) New birds from Angola. Proc. Biol. Soc. Wash. 47: 45-48.

Boscolo, D., Metzger, J. P. and Vielliard, J. M. E. (2006) Efficiency of playback for assessing the occurrence of five bird species in Brazilian Atlantic Forest fragments. An. Acad. Bras. Ciênc. 78: 629-644.

Brooke, R. K. (1970) Geographical variation and distribution in Apus barbatus, A. bradfieldi and A. niansae. (Aves: Apodidae). Durban Mus. Novit. 8: 363-374.

Burgess, N., D'Amico Hales, J., Underwood, E., Dinerstein, E., Olson, D., Itoua, I., Schipper, J., Ricketts, T. and Newman, K. eds. (2004) Terrestrial ecoregions of Africa and Madagascar: a conservation assessment. Washington: Island Press.

Cohen, C., Spottiswoode, C. and Rossouw, J. (2006) Southern African birdfinder. Cape Town: Struik Publishers.

Collar, N. J. and Stuart, S. N. (1988) Key forests for threatened birds in Africa. Cam- bridge, UK: International Council for Bird Preservation. (ICBP Monograph No 3).

Dean, W. R. J. (200o) The birds of Angola. Tring, UK: British Ornithologists' Union. (BOU Checklist series 18).

Dean, W. R. J. (2001) Angola. Pages 71-91 in L. D. C. Fishpool and M. I. Evans, eds. Important bird areas in Africa and associated islands: priority sites for conservation. Newbury and Cambridge, UK: Pisces Publications and BirdLife International. (BirdLife Conservation Series No. 11).

Fjeldså, J. and Bowie, R. C. K. (2008) New perspectives on the origin and diversification of Africa's forest avifauna. Afr. J. Ecol. 46: 235-247.

Gill, F., Wright, M. and Donsker, D. (2009) IOC world bird names (version 2.0). http:// www.worldbirdnames.org. Cited 20 Mar 2009.

Google Earth (2009). Google Earth 5.1. http://earth.google.com/

Grimshaw, J. M. (2001) What do we really know about the Afromontane archipelago? Syst. Geogr. Pl. 71: 949-957.

Hall, B. P. (1960) The ecology and taxonomy of some Angolan birds. Bull. Br. Mus. (Nat. Hist.) 6: 367-463.

Heinrich, G. (1958a) Zur Verbreitung und Lebensweise der Vögel von Angola. J. Ornithol. 99: 121-141.

Heinrich, G. (1958b) Zur Verbreitung und Lebensweise der Vögel von Angola. 
Systematischer Teil I (Galli - Muscicapidae). J. Ornithol. 99: 322-362.

Heinrich, G. (1958c) Zur Verbreitung und Lebensweise der Vögel von Angola. Systematischer Teil III (Hirundinidae - Fringillidae). J. Ornithol. 99: 399-421.

Hockey, P. A. R., Dean, W. R. J. and Ryan, P. G. (2005) Roberts - birds of southern Africa, VIIth ed. Cape Town: The Trustees of the John Voelcker Bird Book Fund.

Huntley, B. J. (1974) Outlines of wildlife conservation in Angola. J. S. Afr. Wildl. Managet. Assoc. 5: 157-166.

Huntley, B. J. (1978) Ecosystem conservation in southern Africa. Pp. 1333-1384 in M. J. A. Verger and A. C. Van Bruggen, eds. Biogeography and ecology of southern Africa. The Hague: W. Junk.

Huntley, B. J. and Matos, E. M. (1994) Botanical diversity and its conservation in Angola. Stelitzia 7: 53-74.

IUCN (2001) IUCN Red List categories andcCriteria: Version 3.1. Gland, Switzerland and Cambridge, UK: IUCN Species Survival Commission.

Maley, J. (1991) The African rain forest vegetation and paleoenvironments during late Quaternary. Climate Change 19: 79-98.

Maley, J. (1996) The African rain forest main characteristics of changes in vegetation and climate from the Upper Cretaceous to the Quaternary. Proc. Roy. Soc. Edin. 104B: 31-73.

Mills, M. S. L. (2007) Swierstra's Spurfowl Pternistis swierstrai: a bibliography and summary of museum skins. Bull. ABC 14: 175-180.

Mills, M. S. L. (2009) Vocalisations of Angolan birds: new descriptions and other notes. Bull. $A B C$ 16: 150-166.

Mills, M. S. L. (in press) Angola's central scarp forests: patterns of bird diversity and conservation threats. Biodivers. Conserv.

Mills, M. S. L. and Dean, W. R. J. (2007) Notes on Angolan birds: new country records, range extensions and taxonomic questions. Ostrich 78: 55-63.

Mills, M. S. L., Franke, U., Joseph, G., Miato, F., Milton, S., Monadjem, A., Oschadleus, D. and Dean, W. R. J. (2010) Cataloguing the Lubango bird skin collection: towards an atlas of Angolan bird distributions. Bull. $A B C_{17}$ : 43-53.

Parker, T. A. (1991) On the use of taperecorders in avifaunal survey. Auk 108: 443-444.

Pinto, A. A. (1983) Ornitologia de Angola. Vol. 1. Lisbon: Instituto de Investigacão Cientifica Tropical.

Ryan, P. G., Sinclair, I., Cohen, C., Mills, M. S. L., Spottiswoode, C. N. and Cassidy, R. (2004) The conservation status and vocalisations of threatened birds from the scarp forests of the Western Angola Endemic Bird Area. Bird Conserv. Int. 14: 247-26o.

Silveira, M. de M. 1967. Climas de Angola. Luanda: Serviço Meterológico de Angola.

Sinclair, I. and Ryan, P. (2003) Birds of Africa south of the Sahara. Cape Town: Struik.

Sinclair, I., Spottiswoode, C., Cohen, C. Mills, M., Cassidy, R., Vaz Pinto, P. and Ryan, P. (2004) Birding western Angola. Bull $A B C$ 11: 152-159.

Stattersfield, A. J., Crosby, M. J., Long, A. J. and Wege, D. C. (1998) Endemic bird areas of the world. Cambridge, UK: BirdLife International (BirdLife Conservation Series No. 7).

White, F. (1978) The afromontane region. Pp. 463-513 in M. J. A. Werger, ed. Biogeography and ecology of southern Africa. The Hague: Junk.

White, F. (1981) The history of the Afromontane archipelago and the scientific need for its conservation. Afr. J. Ecol. 19: 33-54.

White, F. (1983) The vegetation of Africa. A descriptive memoir to accompany the UNESCO/AETFAT/UNSO Vegetation Map of Africa (3 Plates, Northwestern Africa, Northeastern Africa, and Southern Africa, 1:5,000,00o). Paris: UNESCO.

\section{MICHAEL S. L. MILLS*}

A. P. Leventis Ornithological Research Institute, University of Jos, PO Box 13404, Jos, Plateau State, Nigeria; DST/NRF Centre of Excellence at the Percy FitzPatrick Institute, University of 
Cape Town, Rondebosch 7701, South Africa; Birding Africa, 21 Newlands Road, Claremont 7708, Cape Town, South Africa.

\section{FABIO OLMOS}

Largo do Paissandú 10o/4c, 01034-010, São Paulo, SP, Brazil.

\section{MARTIM MELO}

DST/NRF Centre of Excellence at the Percy FitzPatrick Institute, University of Cape Town, Rondebosch 7701, South Africa; Centro de Investigação em Biodiversidade e Recursos Genéticos (CIBIO/UP), Campus Agrário de Vairão, 4485-661 Vairão, Portugal.

\section{W. RICHARD J. DEAN}

DST/NRF Centre of Excellence at the Percy FitzPatrick Institute, University of Cape Town, Rondebosch 7701, South Africa.

${ }^{*}$ Author for correspondence; e-mail: michael@birdingafrica.com

Received 23 October 2009; revision accepted 23 May 2010; Published online 11 February 2011 